\title{
Influence of Fertilizing with Nitrogen Fertilizer on the Content of Amino Acids in Sweet Sorghum Grain
}

\author{
N.K.Nokerbekova ${ }^{1}$ ¿ \\ Ye. T.Suleimenov ${ }^{2}$ \\ R.K. Zhapayev ${ }^{3}$
}

'PhD Doctoral Student, Kazakh National Agrarian University, O50010, Almaty, Republic of Kazakhstan Email:nnazitimail.ru

"Candidates of Agricultural Sciences, Kazakh Research Institute of Agriculture and Plant growing", 040909, Almaty Region, Republic of Kazakhstan

${ }^{3}$ Candidates of Agricultural Sciences International Maize and Wheat Improvement Center; CIMMYT, 050035,

Almaty, Republic of Kazakhstan

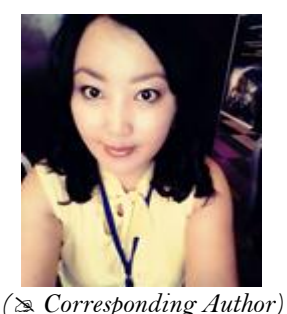

\begin{abstract}
Three-year results of studies on the effect of fertilizing nitrogen fertilizer on the content of amino acids in the grain of sweet sorghum of Kazakhstanskoe 16 and Kazakhstanskoe 20 varieties on irrigated light chestnut soils of the southeast of Kazakhstan are presented.Nitrogen fertilizers are one of the effective means of increasing the protein content of sweet sorghum. The later nitrogen is introduced as a second fertilizer in a dose of N50 in the period of its vegetation, the more effective its effect on the increase in the protein content of the grain. The amount of nitrogen introduced into the soil is of great importance. The number of essential amino acids in sweet sorghum depended on the norms of applying nitrogen fertilizers. The higher is the norm of nitrogen, the more it accumulates in the grain of the protein. At the same time, when nitrogen was added in two terms, the number of such essential amino acids as valine, leucine, isoleucine, and threonine increased significantly, which increases the biological value of the total protein. Therefore, it is possible not only to increase the yield, but also to increase the collection of protein from a unit of area by scientifically substantiating the use of nitrogen fertilizers for sweet sorghum.
\end{abstract}

Keywords: Sweet sorghum, Fertilizer, Fertilizing, Amino acids, Variety, Ground, Soil supply.

Citation | N.K.Nokerbekova; Ye. T.Suleimenov; R.K. Zhapayev (2018). Influence of Fertilizing with Nitrogen Fertilizer on the Content of Amino Acids in Sweet Sorghum Grain. Agriculture and Food Sciences Research, 5(2): 64-67. History:

Received: 5 June 2018

Revised: 9 August 2018

Accepted: 12 September 2018

Published: 15 October 2018

Licensed: This work is licensed under a Creative Commons

Attribution 3.0 License (oc)

Publisher: Asian Online Journal Publishing Group
Contribution/Acknowledgement: All authors contributed to the conception and design of the study.

Funding: This study received no specific financial support.

Competing Interests: The authors declare that they have no conflict of interests.

Transparency: The authors confirm that the manuscript is an honest, accurate, and transparent account of the study was reported; that no vital features of the study have been omitted; and that any discrepancies from the study as planned have been explained.

Ethical: This study follows all ethical practices during writing.

\section{Contents}

1. Introduction 65

2. Methods 65

References.. 


\section{Introduction}

The achievements of national and world science in recent years in fodder production convincingly show that it is possible to optimize the feeding of farm animals through the use of new higher-nutrient crops, one of which is sorghum. However, new varieties of sorghum can differ greatly from traditional sorghum and this can not be ignored when they are included in diets.

Generally, information on nutritional and chemical composition of feeds used in diets is taken from directories that do not take into account varietal characteristics, soil, climatic and other peculiarities of plant cultivation. Therefore, the most reliable is the determination of feed nutrition before feeding animals under laboratory conditions [1].

Amino acid nutrition takes a special place in the physiology of nutrition of highly productive animals. Effective and cost-effective production of livestock products is inconceivable without the right combination of amino acids in the diet. On the one hand, the lack of one or the other amino acid interferes with the synthesis of protein and inhibits growth and productivity. On the other hand, excess nitrogen in the diet leads to additional energy consumption and increases the burden on the kidneys and the body as a whole. Therefore, at the present time there is an increasing application of the concept of "ideal protein", the essence of which is to give the animal as many amino acids as it needs, no more and no less. The quality of the fodder protein is determined from the point of view of the animals' need for amino acids, firstly, the amino acid profile, which represents the ratio of essential amino acids in the protein and, secondly, their availability for metabolism and growth [2].

The content of protein and amino acids is one of the most important characteristics of the biological value of grain. The amino acid composition is used as a biochemical criterion for the biological value of fodder and food products (by the total content of essential amino acids). Amino acids are the structural units of protein molecules involved in all processes occurring in the body of humans and animals. Without proteins, life, growth and development of the body are impossible. Proteins perform specific functions in the cell: enzymatic, construction, regulatory, etc. $3 \%$ reduction of protein in the diet of the recommended standard causes a violation of the production of enzymes and, accordingly, the absorption of essential nutrients. Deficiency of proteins stimulates the search for new varieties and hybrids with a high protein content, with a well-balanced amino acid composition that could be used in breeding programs to create new improved varieties. As the main protein-containing raw material, the leading role belongs to cereal crops. Globally, about $70 \%$ of the needs of mankind in proteins are covered by grain - either directly from food, or indirectly by feeding it to animals for meat production. Consequently, plant storage proteins serve as the basis for human nutrition [3].

As known, proteins consist of amino acids, while some of them - irreplaceable - must necessarily come from feeds, since they are not synthesized in sufficient quantities in the animal's body. The use of protein deteriorates, metabolism is dsturbed and productivity declines because of lack or absence of these amino acids in the rations of animals. Critical essential amino acids are lysine and methionine.

Amino acids are the main subunits which build molecules of all protein substances. As the amount of protein increases, so does the content of amino acids. The sum of amino acids in the protein of sorghum grain is lower than in the protein of corn grain [4].

Sorghum is a grain and fodder crop, anditis highly competitive with corn in terms of grain yield and green mass, and in some cases it exceeds it, especially in areas with unfavorable soil and climatic conditions. Taking into account the prospects of using sorghum grain as a concentrated feed and source material for breeding, in recent years the chemical grain composition of local and selection sorghum varieties grown under irrigation conditions has been studied $[5,6]$.

The task of obtaining a high-quality, environmentally friendly and balanced agricultural products, in particular forage and food grains, has always been and remains relevant at all times [3.p 1].

The protein contains 20 amino acids: alanine, arginine, aspartic acid, valine, glutamic acid, histidine, isoleucine, leucine, lysine, methionine, oxyproline, ornithine, proline, serine, threonine, tryptophan, tyrosine, phenylalanine, cystine, cysteine and two amide - asparagine and luteamine. For animals and humans, essential amino acids are valine, isoleucine, leucine, lysine, methionine, threonine, tryptophan and phenylalanine [7-9].

The purpose of our research was to study the effects of nitrogen fertilization on the amino acid composition of the grain protein of sweet sorghum varietiescultivated on light chestnut soils of the southeast of Kazakhstan, with different supply of soils with mobile phosphorus.

\section{Methods}

Field research was conducted in 2015-2017 on irrigated light chestnut soil in the foothills of the Zailiyskiy Alatau at a different level of soil supply with mobile phosphorus. Agrochemical characteristics of light chestnut soils: humus content - 2,34-2,54\%, alkaline hydrolyzable nitrogen - 81,2-97,7 $\mathrm{mg} / \mathrm{kg}$ and exchange potassium $320-340 \mathrm{mg} / \mathrm{kg}$ soil. The experiment scheme included the following options: 1 - control (without fertilizers); 2 $\mathrm{N}_{50}$ (fertilizing in the phase of 3-5 leaves); $3-\mathrm{N}_{100}$ (fertilizingwith $\mathrm{N}_{50}$ in the phase of 3-5 leaves $+\mathrm{N}_{50}$ in the phase of 6-8 leaves). The experiments were based on two grounds of supply with mobile phosphorus according to Machigin: (average $30-35 \mathrm{mg} / \mathrm{kg}$ soil) - ground 1 and elevated $(40-45 \mathrm{mg} / \mathrm{kg}$ soil) - ground 2 . Nitrogen fertilizers were added in the form of ammonium nitrate $(34 \%)$.

The objects of research were varieties of sweet sorghum - Kazakhstanskoe 16 and Kazakhstanskoe 20. Field experience was laid in 4-fold replication with the use of agricultural techniques adopted for this zone. Accompanying analyzes of plant samples were carried out according to generally accepted procedures: total nitrogen, total phosphorus and total potassium in plants - after wet ashing of plant material from one sample according to Kjeldahl, colorimetrically, on a flame photometer. Determination of proteinogenic amino acids was carried out by the method of capillary electrophoresis.

Statistical processing of the research results was carried out according to the methodology of Dospehov [10]. using the Agros program (version 2.09) according to Martynov [11]. 


\section{Research Results}

By the conventional method, we have determined protein and a number of essential and other amino acids. The data of Table. 1 show that the content of essential amino acids in sweet sorghum grain depended on the period of application of nitrogen fertilizers. The later nitrogen was introduced into the soil, the more amino acids accumulated in the grain.

Table-1. The content of essential amino acids of grain protein in varieties of sweet sorghum, depending on the norms of nitrogen fertilizers, $\mathrm{g} / 100 \mathrm{~g}$, average for 2015-2017

\begin{tabular}{|c|c|c|c|c|c|c|c|}
\hline \multirow[t]{4}{*}{ № } & \multirow[t]{4}{*}{ Aminoacids } & \multicolumn{6}{|c|}{ Sweet sorghum varieties } \\
\hline & & \multicolumn{3}{|c|}{ Kazakhstanskoe 16} & \multicolumn{3}{|c|}{ Kazakhstanskoe 20} \\
\hline & & \multicolumn{3}{|c|}{ Experiment Variants } & \multicolumn{3}{|c|}{ Experiment Variants } \\
\hline & & Control & $\mathbf{N}_{50}$ & $\mathbf{N}_{100}$ & Control & $\mathbf{N}_{50}$ & $\mathbf{N}_{100}$ \\
\hline 1 & lysine & $0,13 \pm 0,04$ & $0,11 \pm 0,04$ & $0,12 \pm 0,04$ & $0,12 \pm 0,04$ & $0,16 \pm 0,05$ & $0,18 \pm 0,06$ \\
\hline 2 & methionine & $0,09 \pm 0,03$ & $0,09 \pm 0,03$ & $0,09 \pm 0,03$ & $0,08 \pm 0,03$ & $0,09 \pm 0,03$ & $0,11 \pm 0,04$ \\
\hline 3 & leucine + isoleucine & $0,37 \pm 0,11$ & $0,38 \pm 0,10$ & $0,46 \pm 0,12$ & $0,39 \pm 0,10$ & $0,43 \pm 0,11$ & $0,39 \pm 0,10$ \\
\hline 4 & phenylalanine & $0,21 \pm 0,06$ & $0,25 \pm 0,07$ & $0,35 \pm 0,11$ & $0,22 \pm 0,07$ & $0,35 \pm 0,10$ & $0,30 \pm 0,09$ \\
\hline 5 & threonine & $0,18 \pm 0,07$ & $0,15 \pm 0,06$ & $0,21 \pm 0,09$ & $0,18 \pm 0,07$ & $0,20 \pm 0,08$ & $0,24 \pm 0,10$ \\
\hline 6 & valine & $0,23 \pm 0,11$ & $0,25 \pm 0,10$ & $0,30 \pm 0,12$ & $0,25 \pm 0,10$ & $0,28 \pm 0,11$ & $0,28 \pm 0,11$ \\
\hline & Amount & 1,21 & 1,23 & 1,53 & 1,24 & 1,51 & 1,50 \\
\hline
\end{tabular}

As the results of the research showed, the introduced increasing rates of nitrogen fertilizers positively influenced both the irreplaceable and the remaining amino acid composition of sweet sorghum and, at the same time, it depended on the biological characteristics of varieties.

The content of individual types of amino acids also varied depending on the norms of nitrogen fertilizers. Thus, in the protein of the Kazakhstanskoe 16 and the Kazakhstanskoe 20 in the $\mathrm{N}_{50}$ variant of the increased ground, the methionine content was 0,09-0,09 $\mathrm{g} / 100 \mathrm{~g}$, threonine $0,15-0,20 \mathrm{~g} / 100 \mathrm{~g}$ and valine $0,25-0,28 \mathrm{~g} / 100 \mathrm{~g}$, and in the variant $\mathrm{N}_{100}$ methionine $(0,09-0,11 \mathrm{~g} / 100 \mathrm{~g})$ and threonine $(0,21-0,24 \mathrm{~g} / 100 \mathrm{~g})$, that is, it was at the level of control option.

The effect of fertilizers was on such kinds of amino acids as lysine, phenylalanine and valine, where the content increased on the average in varieties to 0,$15 ; 0,32$ and $0,29 \mathrm{~g} / 100 \mathrm{~g}$, respectively, against the variant without fertilizers 0,$12 ; 0,22$ and $0,24 \mathrm{~g} / 100 \mathrm{~g}$. It is known from the literature that the last indispensable amino acid is a precursor for the formation of phytohormone indolylacetic acid and vitamin PP, whose role in plant life is well known [12, 13].

The maximum value for the content of both control and fertilized variants was noted for leucine+isoleucine respectively, in the Kazakhstanskoe $16-0,37$ and 0,38-0,46 g/100g, and in the Kazakhstanskoe 20 - 0,39 and 0,39$0,43 \mathrm{~g} / 100 \mathrm{~g}$.

Thus, we can say that the variety Kazakhstanskoe 20 is more responsive to the introduction of nitrogen fertilizers into the fertilizing, the synthesis of the amino acid is enhanced, and therefore the total amount of amino acids of the protein in the grain also increases. The ratio of amino acid in sweet sorghum grain depends on various environmental factors. The introduction of fertilizers leads to a change in the ratio of amino acids in the grain of sweet sorghum. In the variant $\mathrm{N}_{50}$ of Kazakhstanskoe 16 valine amplifies, and also the activity of glycine and methionine decreases.

The total content of essential amino acids in Kazakhstanskoe 20 was slightly higher in variant $\mathrm{N}_{50}$ than in grain of Kazakhstanskoye 16, and in variant $\mathrm{N}_{100}$ it was the same (Table 1). Thus, the sum of essential amino acids in the Kazakhstanskoe 16 in variants $\mathrm{N}_{50}$ and $\mathrm{N}_{100}$ was 1,23 and 1,53 g/100 g, respectively, with a control content of $1,21 \mathrm{~g} / 100 \mathrm{~g}$, whereas in the Kazakhstanskoe 20 it was 1,51 and 1,50 g/ $100 \mathrm{~g}$ with a control of $1,24 \mathrm{~g} / 100 \mathrm{~g}$.

The content of the remaining amino acids of the protein in the varieties of Kazakhstanskoe 16 and Kazakhstanskoe 20 varies considerably in $\mathrm{N}_{50}$ and $\mathrm{N}_{100}$ variants of the raised ground, especially arginine (0,18; $0,34$ and 0,$33 ; 0,35 \mathrm{~g} / 100 \mathrm{~g})$, tyrosine $(0,11 ; 0,16$ and 0,$14 ; 0,14 \mathrm{~g} / 100 \mathrm{~g})$, proline $(0,48 ; 0,55 \mathrm{and} 0,58 ; 0,46$ $\mathrm{g} / 100 \mathrm{~g})$, serine $(0,19 ; 0,23$ and 0,$21 ; 0,22 \mathrm{~g} / 100 \mathrm{~g})$, alanine (0,37; 0,43 and 0,43; 0,39 g/ $100 \mathrm{~g})$, glycine (0,21; $0,20$ and 0,$20 ; 0,20 \mathrm{~g} / 100 \mathrm{~g})$, glutamic acid (1,20;1,26 and 1,00; $0,80 \mathrm{~g} / 100 \mathrm{~g})$, aspartic acid (2,48, 2,61 and 2,79 ; $2,89 \mathrm{~g} / 100 \mathrm{~g})$ and cystine $(0,17 ; 0,19$ and 0,$22 ; 0,21 \mathrm{~g} / 100 \mathrm{~g})$, respectively (Table 2$)$.

Table-2. The content of essential amino acids of grain protein in varieties of sweet sorghum, depending on the norms of nitrogen fertilizers, $\mathrm{g} / 100 \mathrm{~g}$, average for2015-2017

\begin{tabular}{|c|c|c|c|c|c|c|c|}
\hline \multirow[t]{4}{*}{ № } & \multirow[t]{4}{*}{ Amino acids } & \multicolumn{6}{|c|}{ Sweet sorghum variety } \\
\hline & & \multicolumn{3}{|c|}{ Kazakhstanskoe 16} & \multicolumn{3}{|c|}{ Kazakhstanskoe 20} \\
\hline & & \multicolumn{3}{|c|}{ Experiment Variants } & \multicolumn{3}{|c|}{ Experiment Variants } \\
\hline & & Control & $\mathbf{N}_{50}$ & $\mathbf{N}_{100}$ & Control & $\mathbf{N}_{50}$ & $\mathbf{N}_{100}$ \\
\hline 7 & arginine & $0,28 \pm 0,11$ & $0,18 \pm 0,07$ & $0,34 \pm 0,13$ & $0,14 \pm 0,06$ & $0,33 \pm 0,13$ & $0,35 \pm 0,14$ \\
\hline 8 & tyrosine & $0,17 \pm 0,05$ & $0,11 \pm 0,03$ & $0,16 \pm 0,05$ & $0,13 \pm 0,04$ & $0,14 \pm 0,04$ & $0,14 \pm 0,04$ \\
\hline 9 & proline & $0,40 \pm 0,13$ & $0,48 \pm 0,11$ & $0,55 \pm 0,14$ & $0,49 \pm 0,13$ & $0,58 \pm 0,15$ & $0,46 \pm 0,12$ \\
\hline 10 & serine & $0,18 \pm 0,07$ & $0,19 \pm 0,05$ & $0,23 \pm 0,06$ & $0,21 \pm 0,05$ & $0,21 \pm 0,06$ & $0,22 \pm 0,06$ \\
\hline 11 & alanine & $0,37 \pm 0,13$ & $0,37 \pm 0,10$ & $0,43 \pm 0,11$ & $0,39 \pm 0,10$ & $0,43 \pm 0,11$ & $0,39 \pm 0,10$ \\
\hline 12 & glycine & $0,20 \pm 0,07$ & $0,21 \pm 0,07$ & $0,20 \pm 0,07$ & $0,18 \pm 0,06$ & $0,20 \pm 0,07$ & $0,20 \pm 0,07$ \\
\hline 13 & glutamic acid & $0,87 \pm 0,48$ & $1,20 \pm 0,35$ & $1,26 \pm 0,50$ & $0,99 \pm 0,39$ & $1,00 \pm 0,40$ & $0,80 \pm 0,32$ \\
\hline 14 & aspartic acid & $2,49 \pm 1,16$ & $2,48 \pm 0,87$ & $2,61 \pm 1,04$ & $2,12 \pm 0,85$ & $2,79 \pm 1,12$ & $2,89 \pm 1,16$ \\
\hline \multirow[t]{3}{*}{15} & cystine & $0,19 \pm 0,09$ & $0,17 \pm 0,08$ & $0,19 \pm 0,09$ & $0,17 \pm 0,08$ & $0,22 \pm 0,11$ & $0,21 \pm 0,11$ \\
\hline & Amount & 5,15 & 5,39 & 5,97 & 4,82 & 5,90 & 5,66 \\
\hline & Total amount & 6,36 & 6,62 & 7,50 & 6,06 & 7,41 & 7,16 \\
\hline
\end{tabular}

Data on both the amount of the essential and the total amount of amino acids show that they depended on the 
norms of nitrogen fertilizers and the biological characteristics of varieties. So, if the amount of the essential amino acids in the variety Kazakhstanskoe 16 in variants $\mathbf{N}_{50}$ and $\mathrm{N}_{100}$ were respectively 5,39 and 5,97 $\mathrm{g} / 100 \mathrm{~g}$, then in the Kazakhstanskoe 20 it was 5,90 and $5,66 \mathrm{~g} / 100 \mathrm{~g}$. The total amount of amino acids was, respectively, according to the variants of the experiment in the Kazakhstanskoe 16 were 6,62 and 7,50 in the Kazakhstanskoe 20 variety $-7,41$ and $7,16 \mathrm{~g} / 100 \mathrm{~g}$. At the same time, in the control variant, these indicators were respectively in the Kazakhstanskoe 16, 5,15 and 6,36 for the Kazakhstanskoe $20-4,82$ and 6,06 g/100 g.

To conclude, nitrogen fertilizers are one of the effective means of increasing the protein content of sweet sorghum. If you introduce nitrogen during its growing season later, the more effective its effect on the increase in the protein content of the grain. The amount of nitrogen introduced into the soil is of great importance. The higher the dose of nitrogen, the more it accumulates in the protein grain. At the same time, when nitrogen was added in two terms, the number of such essential amino acids as valine, leucine, isoleucine, and threonine increased significantly, which increases the biological value of the total protein. Therefore, by scientifically substantiating the use of nitrogen fertilizers for sweet sorghum, it is possible not only to increase the yield, but also to increase the collection of protein from a unit of area.

\section{References}

[1] A. Astashov, S. Kononenko, and I. Kononenko, "Sorghum as an ingredient of combined fodder for broiler chickens," Maize and Sorghum, vol. 5, pp. 13-14, 2009.

[2] I. S. Kononenko, "Sorghum for broilers," Agrobusiness, vol. 2, pp. 42-43, 2010.

[3] P. KondratenkoYe, O. B. Konstantinova, O. M. Soboleva, Y. A. Izhmulkina, N. V. Verbitskaya, and A. S. Sukhikh, "The content of protein and amino acids in the grain of winter crops that grow in the forest-steppe of the South-East of Western Siberia," Chemistry of Plant Raw Materials, vol. 3, pp. 143-150, 2015.

[4] E. I. Adeyeye, "The intercorrelation of the amino acid quality between raw, steeped and germinated pearl millet (Pennisetum Typhoides) grains," Pakistan Journal of Scientific and Industrial Research, vol. 52, pp. 122-129, 2009.

[5] T. A. Akmaliyev, Efficiency of the use of sorghum and chickpeas in the feeding of milling cows. The author's abstract of the dis.... candidate of agricultural sciences: Ust-Kinelsky, 2015.

A. V. Alabushev, "Unique possibilities of sorghum," Agriculture, vol. 3, p. 19, 2000.

P. AleshinYe and A. A. Ponomarev, Plant physiology. Kolos: Publishing House, 1979.

V. L. Kretovich, Exchange of nitrogen in plants. Moscow: Publishng House Nauka, 1972.

V. L. Kretovich, Fundamentals of plant biochemistry. Moscow: Statepublishing House Vysshaya Shkola, 1961.

B. A. Dospehov, Methodology of field experience (with the Basics of Statistical Processing of Research Results), 5th ed. Moscow: Agroprom Publishing House. (Textbooks and Teaching Aids for Higher Educational Institutions), 1985.

[11] S. P. Martynov, Statistical and biometric-genetic analysis in plant growing and breeding: The Program Package AGROS, Version 2.09: User Manual / - Tver, 1999.

[12] S. Boonchoo, S. Fukai, and S. Hetherington, "Barley yield and grain protein concentration as affected by assimilate and nitrogen availability," Australian Journal of Agricultural Research, vol. 49, pp. 695-706, 1998.Available at: https://doi.org/10.1071/a97103.

[13] M. R. Ebadi, J. Pourreza, J. Jamalian, M. A. Edriss, A. H. Samie, and S. A. Mirhadi, "Amino acid content and availability in low, medium and high Tannin sorghum grain for poultry," International Journal of Poultry Science, vol. 4, pp. 27-31, 2005.Available at: https://doi.org/10.3923/ijps.2005.27.31. 